\title{
A POSTERIORI
}

\section{I}

Anoche soñé que abrazaba tu torso desnudo.

Tu imagen se absorbe entre las sábanas de una cama muy pequeña mis aguas se desbordan

como se palpan los cuerpos en la oscuridad vamos por donde las manos recrean la posibilidad de un poema.

\section{II}

En el lecho te doy más que mi cuerpo:

esencias de cardamomo y anís

leche tibia

incienso

viandas

flores

música

y esta voz que te nombra. 


\section{III}

Si abro la ventana a la posibilidad de tu recuerdo un par de cuervos vuelan por todo lo bajo y el viento helado resopla contra el moribundo árbol de nísperos.

La llaga vuelve a zanjar.

\section{IV}

Las palabras subsisten pero han de retractarse de lo dicho.

Muda la habitación, mudo el silencio

en que los cuerpos entregaron la savia de sus besos.

Miserables, menesterosas, mezquinas

las palabras dichas liban los colibríes.

Tal vez logren describir la belleza oculta en sí misma

como una danza rota, componen el mundo en el que subsisten: las palabras. 